University of Nebraska - Lincoln

DigitalCommons@University of Nebraska - Lincoln

Agronomy \& Horticulture -- Faculty Publications

Agronomy and Horticulture Department

2021

Continuous in situ soil nitrate sensors: The importance of highresolution measurements across time and a comparison with salt extraction-based methods

Yunjiao Zhu

Yuncong Chen

Md. Azahar Ali

Liang Dong

Xinran Wang

See next page for additional authors

Follow this and additional works at: https://digitalcommons.unl.edu/agronomyfacpub

Part of the Agricultural Science Commons, Agriculture Commons, Agronomy and Crop Sciences Commons, Botany Commons, Horticulture Commons, Other Plant Sciences Commons, and the Plant Biology Commons

This Article is brought to you for free and open access by the Agronomy and Horticulture Department at DigitalCommons@University of Nebraska - Lincoln. It has been accepted for inclusion in Agronomy \& Horticulture -Faculty Publications by an authorized administrator of DigitalCommons@University of Nebraska - Lincoln. 


\section{Authors}

Yunjiao Zhu, Yuncong Chen, Md. Azahar Ali, Liang Dong, Xinran Wang, Sotirios V. Archontoulis, James Schnable, and Michael J. Castellano 


\title{
Continuous in situ soil nitrate sensors: The importance of high-resolution measurements across time and a comparison with salt extraction-based methods
}

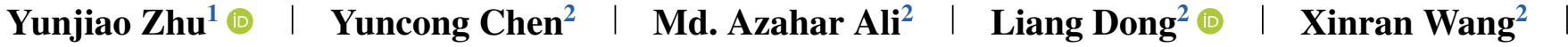 \\ Sotirios V. Archontoulis $^{1} \quad$ ～James C. Schnable ${ }^{3} \quad$ Michael J. Castellano ${ }^{1}$ (i)
}

${ }^{1}$ Department of Agronomy, Iowa State University, Ames, IA 50011, USA

${ }^{2}$ Department of Electrical and Computer Engineering, Iowa State University, Ames, IA 50011, USA

${ }^{3}$ Department of Agronomy and Horticulture, University of

Nebraska-Lincoln, Lincoln, NE 68583, USA

\section{Correspondence}

Michael J. Castellano, Department of Agronomy, Iowa State University, Ames, IA 50011, USA.

Email: castelmj@iastate.edu

Authors Zhu and Chen made equal contributions.

Assigned to Associate Editor Jeffrey A. Bird.

\begin{abstract}
Soil $\mathrm{NO}_{3}{ }^{-}$affects microbial processes, plant productivity, and environmental $\mathrm{N}$ losses. However, the ability to measure soil $\mathrm{NO}_{3}{ }^{-}$is limited by labor-intensive sampling and laboratory analyses. Hence, temporal variation in soil solution $\mathrm{NO}_{3}{ }^{-}$concentration is poorly understood. We evaluated a new potentiometric sensor that continuously measures soil solution $\mathrm{NO}_{3}{ }^{-}$concentration with unprecedented specificity due to a novel membrane that serves as a barrier to interfering anions. First, we compared sensor and salt extraction-based measurements of soil $\mathrm{NO}_{3}{ }^{-}$in well-controlled laboratory conditions. Second, using $60 \mathrm{~d}$ of in situ soil $\mathrm{NO}_{3}{ }^{-}$measurements every $10 \mathrm{~s}$, we quantified temporal variation and the effect of sampling frequency on field estimations of mean daily $\mathrm{NO}_{3}{ }^{-}$concentration both within and across days. In the laboratory, sensors measured soil $\mathrm{NO}_{3}{ }^{-}$concentration without significant difference from theoretical adjusted soil $\mathrm{NO}_{3}{ }^{-}$concentration or conventional salt extractionbased methods. In the field, the sensors demonstrated no within-day pattern in soil $\mathrm{NO}_{3}{ }^{-}$concentration, although individual measurements within a day differed by as much as $20 \%$ from the daily mean. Across days, when soil solution $\mathrm{NO}_{3}{ }^{-}$was dynamic (early spring) and sampling frequency was $>5 \mathrm{~d}$, estimates of mean daily $\mathrm{NO}_{3}{ }^{-}$concentration were $>20 \%$ from the actual mean daily concentration. In situ soil sensors offer potential to improve fundamental and applied sciences. However, in most situations, sensors will measure soil properties in a different manner than conventional salt-extract soil sampling-based approaches. Research will be required to interpret sensor measurements and optimize sensor deployment.
\end{abstract}

\section{1 | INTRODUCTION}

Accurate measurement of soil $\mathrm{NO}_{3}{ }^{-}$is a critical challenge for agriculture and the environment. In experiments and models, soil $\mathrm{NO}_{3}{ }^{-}$concentration has profound effects on primary productivity and environmental $\mathrm{N}$ losses. Whether measured or simulated, accurate soil $\mathrm{NO}_{3}{ }^{-}$data are important to predict and explain critical ecosystem processes such as plant growth, $\mathrm{N}_{2} \mathrm{O}$ emissions, and $\mathrm{NO}_{3}{ }^{-}$leaching (Del Grosso et al., 2008; Iqbal et al., 2018; Loecke et al., 2012). Collection of high-quality soil $\mathrm{NO}_{3}{ }^{-}$data is challenging because soil $\mathrm{NO}_{3}{ }^{-}$concentration is extremely variable in time and space (Archontoulis et al., 2020; Cambardella et al., 1994; Robertson et al., 1988). At a seasonal timescale, 
temporal variability in soil $\mathrm{NO}_{3}{ }^{-}$concentration is largely affected by the balance of annual weather-driven patterns of nitrification, environmental $\mathrm{N}$ losses, and plant $\mathrm{N}$ uptake (Archontoulis et al., 2020; Martinez-Feria et al., 2018). However, temporal variability in soil $\mathrm{NO}_{3}{ }^{-}$concentrations within a single growing season is not well understood because the costs of manual soil sampling and laboratory analyses limit the number of samples across time. In addition, spatial variability in soil $\mathrm{NO}_{3}{ }^{-}$concentrations is extremely high. For example, at a scale of $10-1,000 \mathrm{~m}^{2}$, there may be no spatial autocorrelation between individual soil $\mathrm{NO}_{3}{ }^{-}$concentration measurements (Cambardella et al., 1994).

A lack of high-resolution soil $\mathrm{NO}_{3}{ }^{-}$data limits science. Spatiotemporal variability in soil $\mathrm{NO}_{3}{ }^{-}$creates enormous challenges spanning our basic understanding of the soil $\mathrm{N}$ cycle to the optimization of $\mathrm{N}$ fertilizer inputs. Current approaches to measure soil $\mathrm{NO}_{3}{ }^{-}$require enormous amounts of time. On an individual sampling date, soil must be collected from the field, returned to the laboratory, homogenized, and extracted in a strong salt solution (typically 5:1 ratio of soil/2 M KCl; Hart et al., 1994). Subsequently, $\mathrm{NO}_{3}{ }^{-}$concentration is measured in the salt extract and scaled to milligrams of $\mathrm{NO}_{3}{ }^{-}-\mathrm{N}$ per kilogram of soil, but only after water content of the soil is determined by oven-drying to a constant mass.

Nevertheless, soil $\mathrm{NO}_{3}{ }^{-}$data are critical to our understanding of ecosystem $\mathrm{N}$ dynamics and our ability to manage agricultural systems. For example, in maize (Zea mays L.) production, the late spring soil $\mathrm{NO}_{3}{ }^{-}$test (LSNT) can reduce environmental $\mathrm{N}$ losses and improve profitability (Jaynes et al., 2004). However, farmer adoption of the LSNT is limited due to the high costs of sample collection and analysis (private laboratories charge around US $\$ 10$ per sample for analysis).

Recent innovations in electrical engineering promise new opportunities to measure soil $\mathrm{NO}_{3}{ }^{-}$concentration with low cost and high resolution. Recently, Ali et al. (2019) developed an all-solid-state miniature potentiometric sensor to continuously measure soil solution $\mathrm{NO}_{3}{ }^{-}$concentration with a minimum detection limit of $1 \mathrm{mg} \mathrm{NO}_{3}{ }^{-}-\mathrm{N} \mathrm{L}^{-1}$. This method has the potential to improve $\mathrm{N}$ use efficiency and environment quality. However, the approach has not been tested in the field. In addition, it is unknown how the new sensor measurement corresponds to conventional salt-extract based measurements of soil $\mathrm{NO}_{3}{ }^{-}$concentration. In contrast with salt extractions of soil $\mathrm{NO}_{3}{ }^{-}$, which are reported as milligrams of $\mathrm{NO}_{3}{ }^{-}-\mathrm{N}$ per kilogram of dry soil (Hart et al., 1994), the sensors report milligrams of $\mathrm{NO}_{3}{ }^{-}-\mathrm{N}$ per liter of soil solution.

No method for measuring soil $\mathrm{NO}_{3}{ }^{-}$is "correct." All methods of soil $\mathrm{NO}_{3}{ }^{-}$measurement are simply indicators of the $\mathrm{NO}_{3}{ }^{-}$pool size at a particular time and space. Available methods (e.g., lysimetry, water-based extractions, and salt-based extractions) all produce different measurements of the soil $\mathrm{NO}_{3}{ }^{-}-\mathrm{N}$ pool (Darrouzet-Nardi \& Weintraub, 2014).

The goal of soil $\mathrm{NO}_{3}{ }^{-}$measurement is to produce an indicator of the $\mathrm{NO}_{3}{ }^{-}$pool size that predicts and explains processes

\section{Core Ideas}

- New sensors can measure soil $\mathrm{NO}_{3}{ }^{-}$with similar accuracy as salt extract-based methods.

- There was no diurnal pattern in soil $\mathrm{NO}_{3}{ }^{-}$concentration.

- Within days, instantaneous $\mathrm{NO}_{3}{ }^{-}$concentrations can vary by as much as $20 \%$ of the daily mean.

- Across days, sampling frequencies $>5 \mathrm{~d}$ can result in poor estimation of mean daily $\mathrm{NO}_{3}{ }^{-}$.

- Required sampling frequencies within and across days depend on season and plant growth.

of interest such as plant growth, microbial uptake, or environmental $\mathrm{N}$ losses. All methods have strengths and weaknesses that vary with application. For example, salt- and water-based extractions allow the user to account for spatial variability by subsampling soil at many locations, pooling those subsamples, and making one extraction from a homogenized sample that represents an average soil $\mathrm{NO}_{3}{ }^{-}$concentration in the sampled space (Mueller et al., 2018). However, the approach is laborious in the field and laboratory; as a result, temporal resolution is poor. In contrast, lysimetry and sensors measure the soil solution $\mathrm{NO}_{3}{ }^{-}$concentration at a specific location. Although lysimetry remains laborious and limited in temporal resolution, sensors can record data in real time at frequencies $<1 \mathrm{~s}$. Moreover, when sensor manufacturing is industrialized, it is likely that sensors will cost $<\$ 20$ per unit (L. Dong, personal communication, 2021).

Regardless of method, it appears that future soil $\mathrm{NO}_{3}{ }^{-}$measurements will incorporate in situ soil sensors that record a spatially explicit soil solution $\mathrm{NO}_{3}{ }^{-}$concentration at high temporal resolution. Hence, our objectives were to

1. Compare sensor-based (Ali et al., 2019) and salt extractbased (Hart et al., 1994) measurements of soil $\mathrm{NO}_{3}{ }^{-}$concentration in well-controlled laboratory conditions and in situ field conditions.

2. Use the sensors to explore in situ diurnal variation in soil $\mathrm{NO}_{3}{ }^{-}$concentration.

3. Quantify the effect of sampling frequency on estimations of mean daily in situ $\mathrm{NO}_{3}{ }^{-}$concentration both within and across days.

\section{2 | MATERIALS AND METHODS}

\section{1 | Laboratory experiments}

We conducted two laboratory experiments to test the agreement between sensors and salt extract measurements. In contrast with field experiments, these laboratory experiments aimed to measure a similar pool of $\mathrm{NO}_{3}{ }^{-}$with each method. 
In the first laboratory experiment, the influence of soil moisture on measurement accuracy of the sensor was analyzed. Soils were sampled $(0-30 \mathrm{~cm})$ from the Iowa State University Agronomy and Agricultural Engineering Research Farm $\left(41^{\circ} 55^{\prime} \mathrm{N}, 93^{\circ} 45^{\prime} \mathrm{W}\right)$, air dried, and sieved ( $\left.2 \mathrm{~mm}\right)$. The sampling area contained USDA soil series Webster silty clay loam (fine-loamy, mixed, superactive, mesic Typic Endoaquolls) and Nicollet loam (fine-loamy, mixed, superactive, mesic Aquic Hapludolls). After air drying and sieving, soils were combusted in a muffle furnace at $400{ }^{\circ} \mathrm{C}$ to reduce the effects of microbial processes on soil solution $\mathrm{NO}_{3}{ }^{-}$concentration; our goal was to adjust the $\mathrm{NO}_{3}{ }^{-}$concentration to a constant level, and thus we had to minimize the effects of microbial $\mathrm{N}$ mineralization-immobilization dynamics. Next, the combusted soil was adjusted to a bulk density of $1.25 \mathrm{~g} \mathrm{~cm}^{-3}$ and prepared with two gravimetric moisture contents (20 and $30 \%)$ and three $\mathrm{NO}_{3}{ }^{-}-\mathrm{N}$ soil solution concentration levels $\left(10,100\right.$, and $\left.200 \mathrm{mg} \mathrm{L}^{-1}\right)$ in 118-ml polyethylene cups. We selected these gravimetric water contents and $\mathrm{NO}_{3}{ }^{-}$concentrations because they encompass the typical ranges observed during the growing season in the rainfed Corn Belt (Archontoulis et al., 2020). One sensor was installed in the center of each cup. Sensor measurements were recorded after readings stabilized ( $\sim 60 \mathrm{~min}$ ), and at the same time, soil samples (three per cup) were immediately mixed with $2 \mathrm{M} \mathrm{KCl} \mathrm{(5:1} \mathrm{solu-}$ tion/soil ratio) by reciprocal shaking for $1 \mathrm{~h}$ at $180 \mathrm{rpm}$. The soil slurry was then filtered through preleached Whatman 1 filter paper. The $\mathrm{NO}_{3}{ }^{-}-\mathrm{N}$ concentrations of the filtrate (i.e., extraction) were measured with colorimetry in microplates using the Griess-Ilosvay reaction with $\mathrm{VCl}_{3}$ as a reducing agent and the Berthelot reaction, respectively (Hood-Nowotny et al., 2010). The $\mathrm{NO}_{3}{ }^{-}-\mathrm{N}$ concentrations of the filtrate are scaled to mass of dry soil that is mixed with the $2 \mathrm{M} \mathrm{KCl}$ such that the reported unit is milligrams of $\mathrm{NO}_{3}{ }^{-}-\mathrm{N}$ per kilogram of dry soil.

In the second laboratory experiment, the effect of temperature on the sensor performance was analyzed by measuring the standard $\mathrm{NO}_{3}{ }^{-}-\mathrm{N}$ solutions across four temperatures $(0$, 10,20 , and $\left.30^{\circ} \mathrm{C}\right)$. The stability of each sensor across the four temperatures was obtained by calculating the error rate of the measurement result in each concentration of the $\mathrm{NO}_{3}{ }^{-}$ $\mathrm{N}$ solution. This experiment was performed in solution rather than soil to adjust the temperature more accurately.

\section{2 | Field experiments}

Sensors were deployed in 2019 in a continuous maize $\mathrm{N}$ fertilizer rate trial at the Iowa State University Agricultural Engineering and Agronomy Research Farm in Boone County, Iowa $\left(42.02^{\circ} \mathrm{N}, 93.77^{\circ} \mathrm{W}\right)$. Long-term (35-yr) average annual precipitation and temperature were $87.2 \mathrm{~cm}$ and $9.4{ }^{\circ} \mathrm{C}$. Soil series include Webster (fine-loamy, mixed, superactive, mesic
Typic Hapludolls) and Nicollet (fine-loamy, mixed, superactive, mesic Aquic Hapludolls).

The trial was established in 2017. The experimental design was a randomized complete block design with three $\mathrm{N}$ fertilizer rate treatments $\left(0,168\right.$, and $336 \mathrm{~kg} \mathrm{~N} \mathrm{ha}^{-1}$; onward $\mathrm{N} 0$, $\mathrm{N} 168$, and N336). Each treatment had three replicate plots and was blocked to account for soil series. Corn was planted in all years in all plots and fertilized with hand-broadcast urea prior to planting. The soil was chisel plowed in the fall after harvest and cultivated in the spring prior to corn planting. In 2019, $\mathrm{N}$ fertilizer was applied on 24 April and maize (111 d relative maturity) was planted on 16 May at 80,000 plants $\mathrm{ha}^{-1}$ in 76-cm rows.

In each plot, soil temperature and soil volumetric water content were measured at 15 - and $45-\mathrm{cm}$ depth with commercial soil sensors (METER 5TM). These sensors were placed near the center of each plot between maize rows. The new soil $\mathrm{NO}_{3}{ }^{-}-\mathrm{N}$ sensors were installed in the field on 8 June when corn was at the second leaf growth stage (crop planting in 2019 was delayed across the Corn Belt due to record precipitation). During installation, the sensors were inserted in slurry of soil and water to ensure good sensor-soil contact (a procedure like the installation of lysimeters). The installation depth was $25 \mathrm{~cm}$ in the middle of two maize rows within $25 \mathrm{~cm}$ of the soil moisture and temperature sensors. After field deployment, sensors were retrieved and recalibrated.

Salt extract-based soil $\mathrm{NO}_{3}{ }^{-}$measurements during the sensor measurement period were made on four dates: 13 June, 27 June, 9 July, and 15 July. On each date, three random 0-to$30-\mathrm{cm} \times 2.54-\mathrm{cm}$ soil cores were collected from each plot within $20 \mathrm{~cm}$ of the corresponding sensor. The soil cores were immediately returned to the laboratory and homogenized, and soil $\mathrm{NO}_{3}{ }^{-}$concentration was measured using the salt extraction procedure described above. Although the sensors made point-based measurements at $\sim 25$-cm depth, we sampled from $0-30 \mathrm{~cm}$ because our objective was to compare the sensors to the conventional salt-extraction approach for soil $\mathrm{NO}_{3}{ }^{-}$measurement in midwestern U.S. maize fields (Jaynes et al., 2004).

\section{3 | Soil sensors}

The sensors in this study measured $\mathrm{NO}_{3}{ }^{-}$concentration in the soil solution $\left(\mathrm{mg} \mathrm{NO}_{3}{ }^{-}-\mathrm{N} \mathrm{L}^{-1}\right)$ using a solid-state miniature potentiometric sensor that works in direct contact with soil to measure $\mathrm{NO}_{3}{ }^{-}-\mathrm{N}$ concentration in soil solution with partsper-million (ppm) resolution using a working electrode and a reference electrode. Although the sensors are field deployable for long-term measurement, they are currently hand manufactured by the inventors in an academic laboratory setting; the sensors for use in this work go through strict quality check and systematic calibrations under different conditions in the 
research laboratory (Ali et al., 2019). The major innovation in these sensors is the integration of a $\mathrm{NO}_{3}{ }^{-}$-selective membrane and a solid-state ion-to-electron transducing layer that minimize interference from other anions.

The working electrode is formed from a thin layer of $\mathrm{Ag}$ deposited on a patterned $\mathrm{Au}$ electrode and covered with the ion-to-electron transducing layer and the $\mathrm{NO}_{3}{ }^{-}$-selective membrane. The reference electrode comprises a screenprinted $\mathrm{Ag} / \mathrm{AgCl}$ electrode covered by a protonated Nafion layer to prevent $\mathrm{Cl}^{-}$leaching in long-term measurements. A waterproof epoxy covers the entire surface of the sensor and allows only the center area of the membrane to be exposed to the soil solution.

The sensors provide long-term, continuous measurement of soil solution $\mathrm{NO}_{3}{ }^{-}$concentration at a specific point in space where they are deployed (e.g., $<1 \mathrm{~cm}^{3}$ ); they sense only the solution with which they contact. In the field study reported herein, the sensors were programmed to record one $\mathrm{NO}_{3}{ }^{-}-\mathrm{N}$ concentration per $10 \mathrm{~s}$.

Pre- and post-deployment, the soil $\mathrm{NO}_{3}{ }^{-}$sensors were calibrated with standard $\mathrm{NO}_{3}{ }^{-}-\mathrm{N}$ solutions, using a range that includes soil solution $\mathrm{NO}_{3}{ }^{-}-\mathrm{N}$ concentrations that will be encountered in the sensing environment (for Iowa maize systems, $1-5,000 \mathrm{mg} \mathrm{NO}_{3}{ }^{-}-\mathrm{N} \mathrm{L}^{-1}$ soil solution). Note that most of this range (500-5,000 $\left.\mathrm{mg} \mathrm{L}^{-1}\right)$ is due to the widespread use of concentrated $\mathrm{N}$ fertilizer applications (i.e., "banding"). The sensors were calibrated by recording their voltage responses (in $\mathrm{mV}$ ) after being immersed in standard $\mathrm{NO}_{3}{ }^{-}-\mathrm{N}$ solutions $\left(10,100,200,1,000\right.$, and $\left.5,000 \mathrm{mg} \mathrm{L}^{-1}\right)$ for $3 \mathrm{~min}$. The standard $\mathrm{NO}_{3}{ }^{-}-\mathrm{N}$ solutions were prepared by dissolving $\mathrm{NaNO}_{3}$ in deionized water. The sensors were calibrated in $\mathrm{NO}_{3}{ }^{-}-\mathrm{N}$ solutions from low to high concentrations, repeated three times. The average voltage response for each solution was used to represent the corresponding $\mathrm{NO}_{3}{ }^{-}-\mathrm{N}$ concentration. Sensors were considered functional when the difference between the pre- and post-deployment calibration curves were $<20 \%$. Although this difference may appear to be large, it should be interpreted in the context of exceptionally high within-field spatial variation and minimal spatial autocorrelation in soil $\mathrm{NO}_{3}{ }^{-}-\mathrm{N}$ concentrations (Cambardella et al., 1994). Hence, this is not the largest source of uncertainty.

\section{4 | Salt extraction-based soil nitrate measurement}

In contrast with the soil sensors, which measure the $\mathrm{NO}_{3}{ }^{-}$ concentration in soil solution ( $\mathrm{mg} \mathrm{NO}_{3}{ }^{-}-\mathrm{N} \mathrm{L}^{-1}$ soil solution), salt extract-based soil $\mathrm{NO}_{3}{ }^{-}-\mathrm{N}$ measurements are reported in units of milligrams of $\mathrm{NO}_{3}{ }^{-}-\mathrm{N}$ per kilogram of dry soil. Hence, the transformation of sensor data from milligram of $\mathrm{NO}_{3}{ }^{-}-\mathrm{N}$ per liter to milligrams of $\mathrm{NO}_{3}{ }^{-}-\mathrm{N}$ per kilogram of dry soil was required for comparison of the sensor method with the conventional salt-extract method and requires two coefficients: soil water content and soil bulk density. We tested the sensitivity of the data transformation to uncertainty across relevant ranges of these coefficients. We used Equation 1 to estimate soil gravimetric moisture content $\left(\theta_{\mathrm{m}}\right)$ from volumetric soil moisture content $\left(\theta_{\mathrm{v}}\right)$ sensor data and estimates of soil bulk density $\left(\rho_{\mathrm{b}}\right)$ and water density $\left(\rho_{\mathrm{w}}\right)$, which is assumed to be $1 \mathrm{~g} \mathrm{~cm}^{-3}$. In the calculation, we assumed bulk density was $1.25 \mathrm{~g} \mathrm{~cm}^{-3}$. Then, we used Equation 2 . to convert milligrams of $\mathrm{NO}_{3}{ }^{-}-\mathrm{N}$ per liter of soil solution to milligrams of $\mathrm{NO}_{3}{ }^{-}-\mathrm{N}$ per kilogram of soil. According to the equations, the $\mathrm{NO}_{3}{ }^{-}-\mathrm{N}$ concentration changes linearly with bulk density and volumetric water content. For this analysis, we used ranges of uncertainty in bulk density of 1.15$1.3 \mathrm{~g} \mathrm{~cm}^{-3}$ and volumetric water content of $\pm 10 \%$ difference of the measurement (e.g., $0.30 \pm 0.03 \mathrm{~cm}^{3} \mathrm{H}_{2} \mathrm{O} \mathrm{cm}$ soil).

$$
\theta_{\mathrm{m}}=\theta_{\mathrm{v}} \cdot \rho_{\mathrm{w}} / \rho_{\mathrm{b}}
$$

$$
\mathrm{mg} \mathrm{NO}_{3}{ }^{-}-\mathrm{N} \mathrm{kg}^{-1} \text { soil }=\mathrm{mg} \mathrm{NO}_{3}{ }^{-}-\mathrm{N} \mathrm{L}^{-1} \text { soil solution } \cdot \theta_{\mathrm{m}}
$$

\section{5 | Comparisons of salt extract and sensor measurements}

During the 2019 growing season, 32 pairs of salt extract and sensor-based measurements from 14 sensors in all three $\mathrm{N}$ rate treatments and nine plots were made for the four sampling dates listed above. Some comparisons from particular plots are missing due to sensor failures. These data were used to compare the two methods using converted soil sensor $\mathrm{NO}_{3}{ }^{-}$ $\mathrm{N}$ data from milligrams of $\mathrm{NO}_{3}{ }^{-}-\mathrm{N}$ per liter of soil solution to milligrams of $\mathrm{NO}_{3}{ }^{-}-\mathrm{N}$ per kilogram of dry soil.

We used three quantitative methods to compare the salt extraction-based and sensor-based $\mathrm{NO}_{3}{ }^{-}$measurements. First, we used a linear regression model $(Y=a X+b)$ to describe the relationship between two methods. The coefficient of determination $\left(r^{2}\right)$ was used to quantify the variance in the dependent variable (converted sensor data) that was explained by the independent variable (salt-extract data). We determined whether the slope significantly differed from 1:1. Second, we used Bland-Altman (B\&A) plots (Bland \& Altman, 1986, 1999), which are a more informative graphical method to describe the agreement between a new and established measurement techniques. The B\&A plot analysis is a simple way to evaluate bias between the mean differences of two methods, and to estimate an agreement interval within which lies the 95\% limit of agreement of the second method. In this graphical method, the differences between the two methods are plotted against the averages of the two methods or, when there is an increase in variability of the absolute differences as the 
magnitude of the measurement increases, the percentage differences are plotted against the average of the two methods (Giavarina, 2015). In these plots, the $X$ axis is the mean value of the paired conventional and sensor-based measurements, and the $Y$ axis is the percentage difference of the paired measurements. Horizontal lines are drawn at the mean difference, and at the limits of agreement, which are defined as the mean difference $(d) \pm 1.96 \times$ the SD of the differences. If the differences are normally distributed, $95 \%$ of the limits of agreement will be between $d-1.96 \mathrm{D}$ and $d+1.96 \mathrm{SD}$. Third, we used intraclass correlation coefficients (ICCs), which assess agreement of quantitative measurements in the sense of consistency and conformity between two or more measurements (Fisher, 1954). Consistency is defined as the agreement of two quantitative measurements where neither is assumed "correct" or "standard." Hence, consistency handles questions of intra- as well as interobserver repeatability of measurement scales. In contrast, the concept of conformity is defined as the agreement of a first measurement with a reference that is established as the "standard" (Müller \& Büttner, 1994). Modern ICCs are calculated by mean squares obtained through ANOVA. According to Koo and Li (2016), ICC values $<0.5$ are indicative of poor reliability, values between 0.5 and 0.75 indicate moderate reliability, values between 0.75 and 0.9 indicate good reliability, and values $>0.90$ indicate excellent reliability.

The laboratory experiments allowed us to better control soil $\mathrm{NO}_{3}{ }^{-}$concentrations and evaluate sensor response to soil temperature and water content, thus justifying the field evaluation of the sensors. The in situ field experiments allowed us to compare the similarity of the two methods in the context of environmental variability (i.e., spatiotemporal variation) and methodological differences that necessarily result in different $\mathrm{NO}_{3}{ }^{-}$measurements with each method. Moreover, the field sensor data also allowed us to characterize intra- and interdaily fluctuations of soil solution $\mathrm{NO}_{3}{ }^{-}-\mathrm{N}$ concentration with unprecedented resolution.

\section{6 | Time series analyses of sensor data}

We used time series data analysis to test for temporal patterns of $\mathrm{NO}_{3}{ }^{-}$concentration and soil moisture content. The seasonality of a time series is defined as a pattern that repeats itself over fixed intervals of time (Makridakis et al., 1998). The full (Ha) model for the analysis is $y_{\mathrm{t}}=T_{\mathrm{t}}+S_{t}+R_{\mathrm{t}}$, where $y_{\mathrm{t}}$ is the original data, $T_{\mathrm{t}}$ is trend component, $S_{\mathrm{t}}$ is seasonality component, and $R_{\mathrm{t}}$ is residual component. The null (H0) model $\left(x_{\mathrm{t}}=T_{\mathrm{t}}+R_{\mathrm{t}}\right)$ is the time series after seasonality adjusting. We used a Type I error $p$ value $>.05$ to indicate that there is not enough evidence to reject H0, which means there is a recurrent temporal pattern. In contrast, if the $p$ value was $<.05$, we rejected $\mathrm{H} 0$ indicating the absence of a recurrent tempo- ral pattern. When rejecting $\mathrm{H} 0$, the quantitative measure of seasonality is Fs $=1-\operatorname{Var}\left(R_{\mathrm{t}}\right) / \operatorname{Var}\left(R_{\mathrm{t}}+S_{\mathrm{t}}\right)$. Ultimately the temporal pattern is normalized to a value from 0 to 1 to indicate the degree of presence of the seasonality. A measure near 0 for a certain time series indicates an absence of seasonality, whereas a measure near 1 indicates a strong presence of the seasonality (Wang et al., 2006).

In the early spring, soil $\mathrm{NO}_{3}{ }^{-}-\mathrm{N}$ concentrations are generally stable and high. In the late spring and early summer, soil $\mathrm{NO}_{3}{ }^{-}-\mathrm{N}$ concentrations are generally dynamic and high. In mid- to late summer, soil $\mathrm{NO}_{3}{ }^{-}-\mathrm{N}$ concentrations are generally stable and low due high rates of maize $\mathrm{N}$ uptake. This pattern is widespread and well known in maize-based agroecosystems (Archontoulis et al., 2020). Hence, we used the three periods (8-22 June, 1-15 July, and 1-15 August) to test the effects of sampling frequency on estimates of soil $\mathrm{NO}_{3}{ }^{-}$ $\mathrm{N}$ concentration. Within days, we investigated the effect of intradaily sampling frequency (i.e., every $1-12 \mathrm{~h}$ corresponding to 12-24 samples per day) on actual mean daily soil $\mathrm{NO}_{3}-\mathrm{N}$ concentration calculated from the 10 -s sensor measurements. Across days, we investigated the effect of daily sampling frequency (every $1-7 \mathrm{~d}$ or $2-15$ samples per $15 \mathrm{~d}$ ) on estimates of mean daily $\mathrm{NO}_{3}{ }^{-}-\mathrm{N}$ concentration across the $15-\mathrm{d}$ period calculated from the $10-\mathrm{s}$ measurements. To quantify the effects of sampling frequency on measured soil $\mathrm{NO}_{3}{ }^{-}-\mathrm{N}$ concentration, we used a jackknife subsampling procedure (Parkin, 2008). Using the continuous measurements of $\mathrm{NO}_{3}-\mathrm{N}$, we constructed subsets of hourly or daily concentration data from measured values every $10 \mathrm{~s}$ throughout the sample period (Efron, 1979; Efron \& Gong, 1983). The influence of sampling frequency on the accuracy of $\mathrm{NO}_{3}{ }^{-}-\mathrm{N}$ estimates was obtained by computing the percentage difference of each jackknife subset from the average of the 10-s data.

\section{3 | RESULTS}

\section{1 | Laboratory experiments}

In laboratory comparisons of soil $\mathrm{NO}_{3}{ }^{-}-\mathrm{N}$ concentration after organic matter removal, the salt extract and sensor measurements were similar to the adjusted theoretical soil solution $\mathrm{NO}_{3}{ }^{-}-\mathrm{N}$ concentration (i.e., the targeted $\mathrm{NO}_{3}{ }^{-}-\mathrm{N}$ concentration). Salt extract and sensor measurements did not significantly differ from each other $(P=.95)$ or the theoretical adjusted $\mathrm{NO}_{3}{ }^{-}-\mathrm{N}$ concentration (Figure 1; $P=.99$ ). Percentage differences between the salt extract measurements and adjusted theoretical $\mathrm{NO}_{3}{ }^{-}-\mathrm{N}$ concentrations ranged from -6.5 to $31 \%$, whereas the percentage differences between the sensor measurements and adjusted theoretical concentrations ranged from 0.9 to $22 \%$. (Figure 1).

Temperature had no consistent effect on sensor measurements (Figure 2). The differences between the sensor 

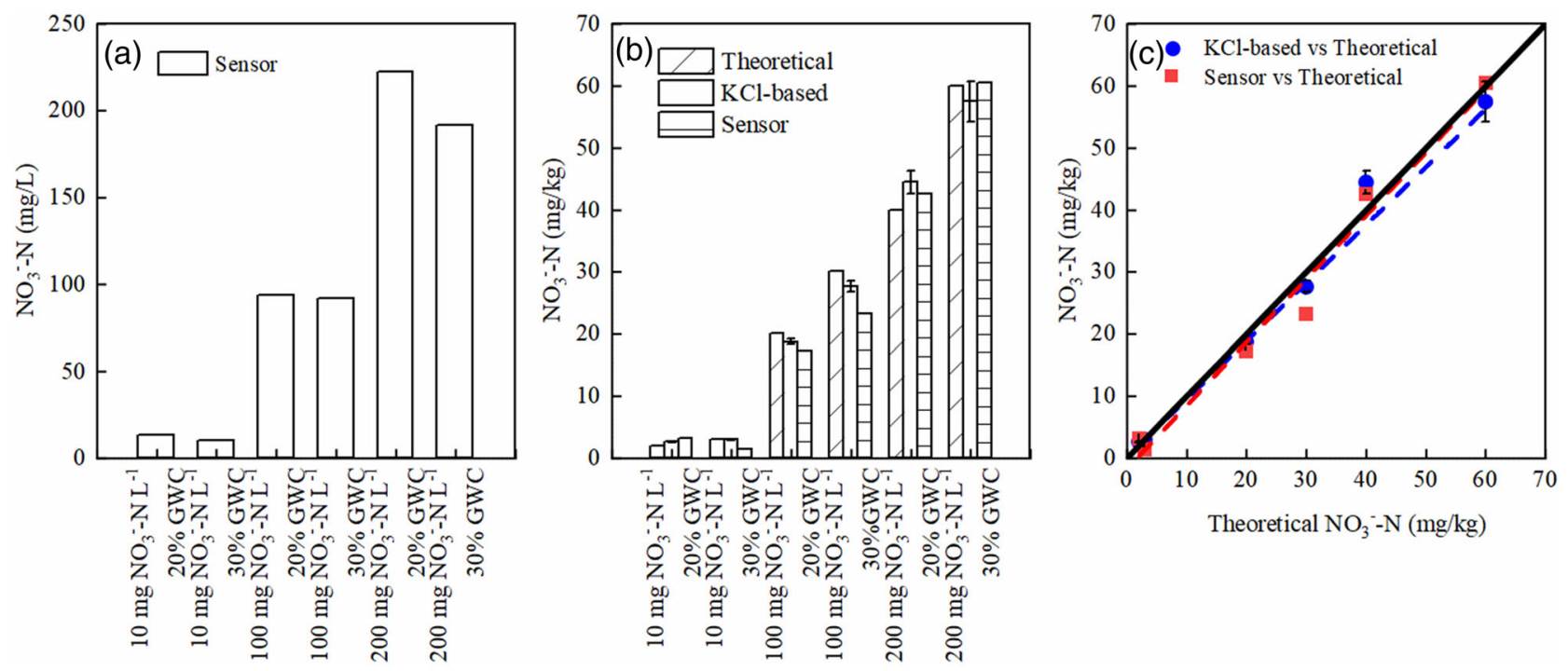

F I G UR E 1 Laboratory-based measurements of $\mathrm{NO}_{3}{ }^{-}$in soils that were adjusted to specific gravimetric water contents and soil solution $\mathrm{NO}_{3}{ }^{-}$ concentrations ("theoretical") after combustion to remove organic matter and reduce microbial mineralization-immobilization. (a) Sensor measurements of theoretical soil solution $\mathrm{NO}_{3}{ }^{-}$concentration. (b) Comparison between salt extract and sensor measurements after adjusting to common units ( $\mathrm{mg} \mathrm{NO}_{3}{ }^{-}-\mathrm{N} \mathrm{kg}^{-1}$ dry soil). Standard errors (only salt extraction-based measurements) indicate standard error of three subsamples from the same experimental unit. (c) Salt extract vs. sensor, salt extract vs. theoretical, and sensor vs. theoretical did not significantly differ from 1.0. The solid line of equality is shown for reference. The dashed lines show linear regression of each comparison. The linear regression for the sensor vs. theoretical is $y=0.9827 x+0.2295, r \check{s}=.99$; the linear regression for the salt-extract vs. theoretical is $y=1.0196 x-1.6779, r \check{s}=.98$. VWC is volumetric water content

measurements and the adjusted theoretical $\mathrm{NO}_{3}{ }^{-}-\mathrm{N}$ concentrations ranged from -24 to $27 \%$. The differences between sensor measurements and prepared solution concentration were not significant (Figure 2, $P=.51$ ).

\section{2 | Field experiments}

Nitrogen fertilizer rate had a significant effect on mean daily soil $\mathrm{NO}_{3}{ }^{-}$concentration as measured with sensor and salt extract methods (Figures 3 and 4). The sensors measured $\mathrm{NO}_{3}{ }^{-}-\mathrm{N}$ concentrations every $10 \mathrm{~s}$ from 8 June to 20 August with some periods of data loss due to battery or electronic failures. Across all sensors, data loss accounted for $32.7 \%$ of the total deployment time. Nitrate concentrations reached a maximum in late June and then decreased until all measurements were lower than $1 \mathrm{mg} \mathrm{NO}_{3}{ }^{-}-\mathrm{N} \mathrm{kg}^{-1}$ dry soil with both sensor and salt-extract methods (Figures 3 and 4). In the zero- $\mathrm{N}$ fertilizer treatments, the mean concentration was $\sim 3 \mathrm{mg} \mathrm{NO}_{3}{ }^{-}-\mathrm{N} \mathrm{kg}^{-1}$ dry soil and the highest concentration was $\sim 20 \mathrm{mg} \mathrm{NO}_{3}{ }^{-} \mathrm{N} \mathrm{kg}^{-1}$ dry soil. In the $168-\mathrm{kg} \mathrm{N}$ fertilizer $\mathrm{ha}^{-1}$ treatments, the mean concentration was $\sim 5 \mathrm{mg} \mathrm{NO}_{3}{ }^{-}-\mathrm{N}$ $\mathrm{kg}^{-1}$ dry soil and the highest concentration was $\sim 35 \mathrm{mg}$ $\mathrm{NO}_{3}{ }^{-}-\mathrm{N} \mathrm{kg}{ }^{-1}$ dry soil. In the 336-kg $\mathrm{N}$ fertilizer ha ${ }^{-1}$ treatments, the mean concentration was $\sim 9 \mathrm{mg} \mathrm{NO}_{3}{ }^{-}-\mathrm{N}$ $\mathrm{kg}^{-1}$ dry soil, and the highest concentration was $\sim 65 \mathrm{mg}$
$\mathrm{NO}_{3}{ }^{-}-\mathrm{N} \mathrm{kg}{ }^{-1}$ dry soil. Figure 4 displays the comparison between salt-extract and sensor measurements of soil $\mathrm{NO}_{3}{ }^{-}$ $\mathrm{N}$ concentration in two example experimental units in field experiments.

The effects of uncertainty in bulk density and volumetric soil water content were less than the variations in $\mathrm{NO}_{3}{ }^{-}$concentrations within and across plots (Supplemental Figure S2). The effects of uncertainty in bulk density and volumetric soil water content change in proportion to bulk density and volumetric soil water content. The effects of uncertainty in bulk density were limited to -4 to $8 \%$. The effects of uncertainty in volumetric water content were limited to $\pm 10 \%$.

We examined 32 pairs of salt extract and sensor-based measurements from all 14 sensors. The relationship between salt extract and sensor measurements did not differ from 1 (Figure 5a). The mean difference between paired salt-extract and sensor measurements was $-22 \%$ (Figure $5 b$ ). Throughout all measurements, the variability in $\mathrm{NO}_{3}{ }^{-}-\mathrm{N}$ concentrations across days within plots was $\pm 99 \%$. As a percentage of the $\mathrm{NO}_{3}{ }^{-}-\mathrm{N}$ concentration, differences between the sensor and salt extract measurements were relatively high when the $\mathrm{NO}_{3}-\mathrm{N}$ concentration was low. However, the percentage difference was relatively low when the mean concentration of the paired measurements was management relevant (i.e., $>10 \mathrm{mg} \mathrm{NO}_{3}{ }^{-}-\mathrm{N} \mathrm{kg}^{-1}$ ). According to published guidelines (Koo \& Li, 2016), the intraclass correlation (ICC) that 

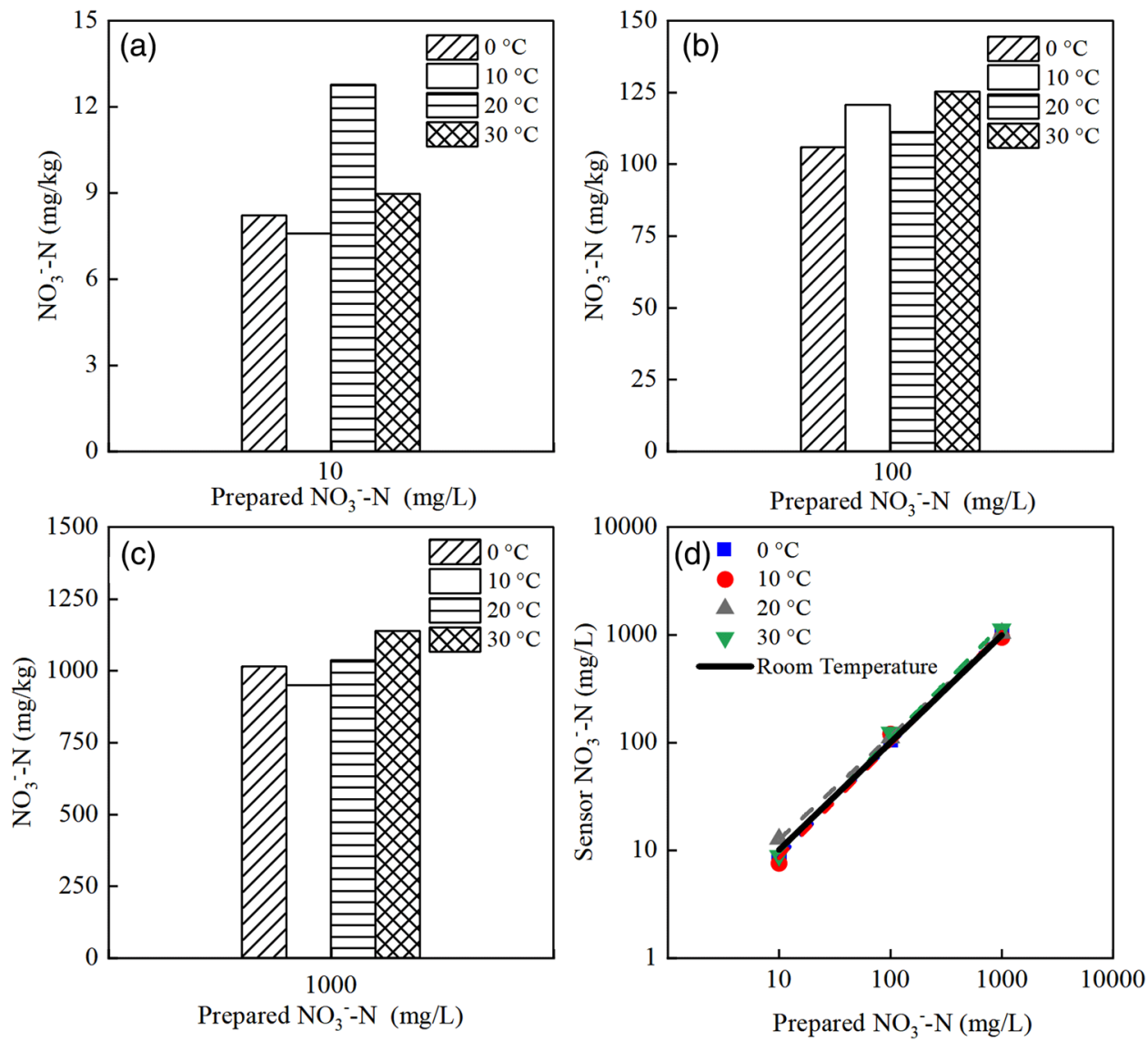

F I G U R E 2 (a-c) Comparison of $\mathrm{NO}_{3}{ }^{-}-\mathrm{N}$ concentration in laboratory experiments across four different temperatures $\left(0,10,20\right.$, and $\left.30{ }^{\circ} \mathrm{C}\right)$ and (d) three prepared $\mathrm{NO}_{3}{ }^{-}-\mathrm{N}$ concentrations $\left(10,100\right.$, and 1,000 mg L $\left.{ }^{-1}\right)$. The solid line of room temperature is shown for reference; points on this line are from the sensor calibration procedure under room temperature. The dashed lines show linear regression of each temperature. The linear regression for $0{ }^{\circ} \mathrm{C}$ is $y=1.04572 x-0.10963, r \check{s}=1$; the linear regression for $10{ }^{\circ} \mathrm{C}$ is $y=1.04873 x-0.11823, r \check{s}=.99$; the linear regression for $20{ }^{\circ} \mathrm{C}$ is $y=0.95468 x+0.14644, r \check{s}=.99$; and the linear regression for $30^{\circ} \mathrm{C}$ is $y=1.05184 x-0.06813, r \check{s}=.98$

was used to quantify the reliability of sensor measurements indicated "good" correlation: $\rho=.87$.

\section{3 | Temporal analyses of sensor data}

Time series analysis showed there was no intradaily (i.e., diurnal) pattern in the $\mathrm{NO}_{3}{ }^{-}-\mathrm{N}$ concentration $(P>.99)$. Despite times when soil moisture content showed a strong intradaily pattern (which is well known to occur; Jackson et al., 1997), there was no intradaily pattern in the corresponding $\mathrm{NO}_{3}{ }^{-}-\mathrm{N}$ concentration (e.g., Figure 6). For example, from 8 to 13 June, soil moisture content exhibited a strong diurnal temporal pattern $(\mathrm{Fs}=0.7157)$, but there was no pattern in the $\mathrm{NO}_{3}{ }^{-}-\mathrm{N}$ concentration ( $\mathrm{Fs}=0.0978$ ).

As a percentage of the daily mean, the diurnal range in soil moisture content was extremely small relative to the diurnal range of $\mathrm{NO}_{3}{ }^{-}-\mathrm{N}$ concentration. Figure 7 displays the daily range of soil $\mathrm{NO}_{3}{ }^{-}-\mathrm{N}$ concentration from 10-s measurements across $9 \mathrm{~d}$. During this time, the diurnal range of soil $\mathrm{NO}_{3}{ }^{-}-$
$\mathrm{N}$ concentration spanned \pm 0.85 to $\pm 7.8 \%$ of the daily mean, whereas the diurnal range of soil water content spanned \pm 0.25 to $\pm 0.52 \%$ of the daily mean.

Within days, there was an effect of intradaily sampling time on estimated mean $\mathrm{NO}_{3}{ }^{-}-\mathrm{N}$ concentration calculated from the 10-s measurements. Although the effect was random due to the lack of diurnal pattern in $\mathrm{NO}_{3}{ }^{-}-\mathrm{N}$ concentration, it was large during times of the year when soil $\mathrm{NO}_{3}{ }^{-}-\mathrm{N}$ concentration was high and dynamic (e.g., Figures 8 and 9). In the early spring when soil $\mathrm{NO}_{3}{ }^{-}-\mathrm{N}$ concentration was high but stable (8-22 June), the number of measurements per day (224) had little effect on the estimate of actual mean $\mathrm{NO}_{3}-\mathrm{N}$ concentration for that day; the mean of two measurements, separated by $12 \mathrm{~h}$, were within $5 \%$ of the actual mean value for the day calculated from the 10-s measurements. In contrast, when $\mathrm{NO}_{3}{ }^{-}-\mathrm{N}$ concentration was high and dynamic (1-15 July), sampling intervals $<4$ h (i.e., 6 measurements per day) were required to provide an estimate that was within $5 \%$ of the actual daily mean of the 10 -s measurements. When $\mathrm{NO}_{3}{ }^{-}$ concentration was low and stable (1-15 August), percentage 


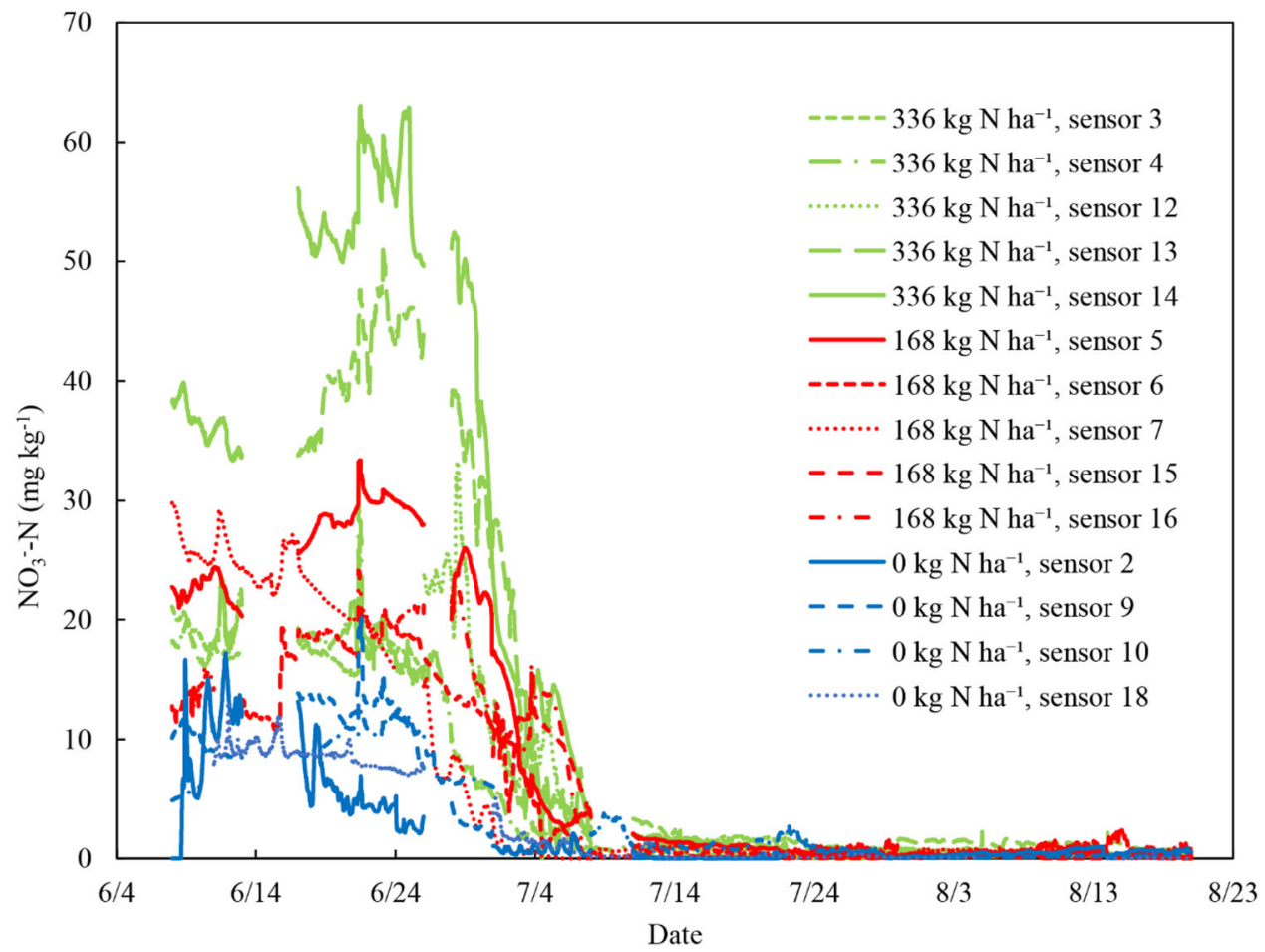

F I G U R E 3 Soil solution $\mathrm{NO}_{3}{ }^{-}$concentration measured every $10 \mathrm{~s}$ in a N fertilizer rate experiment with 14 sensors in three $\mathrm{N}$ fertilizer treatments: 0,168 , and $336 \mathrm{~kg} \mathrm{~N}$ ha $^{-1}$

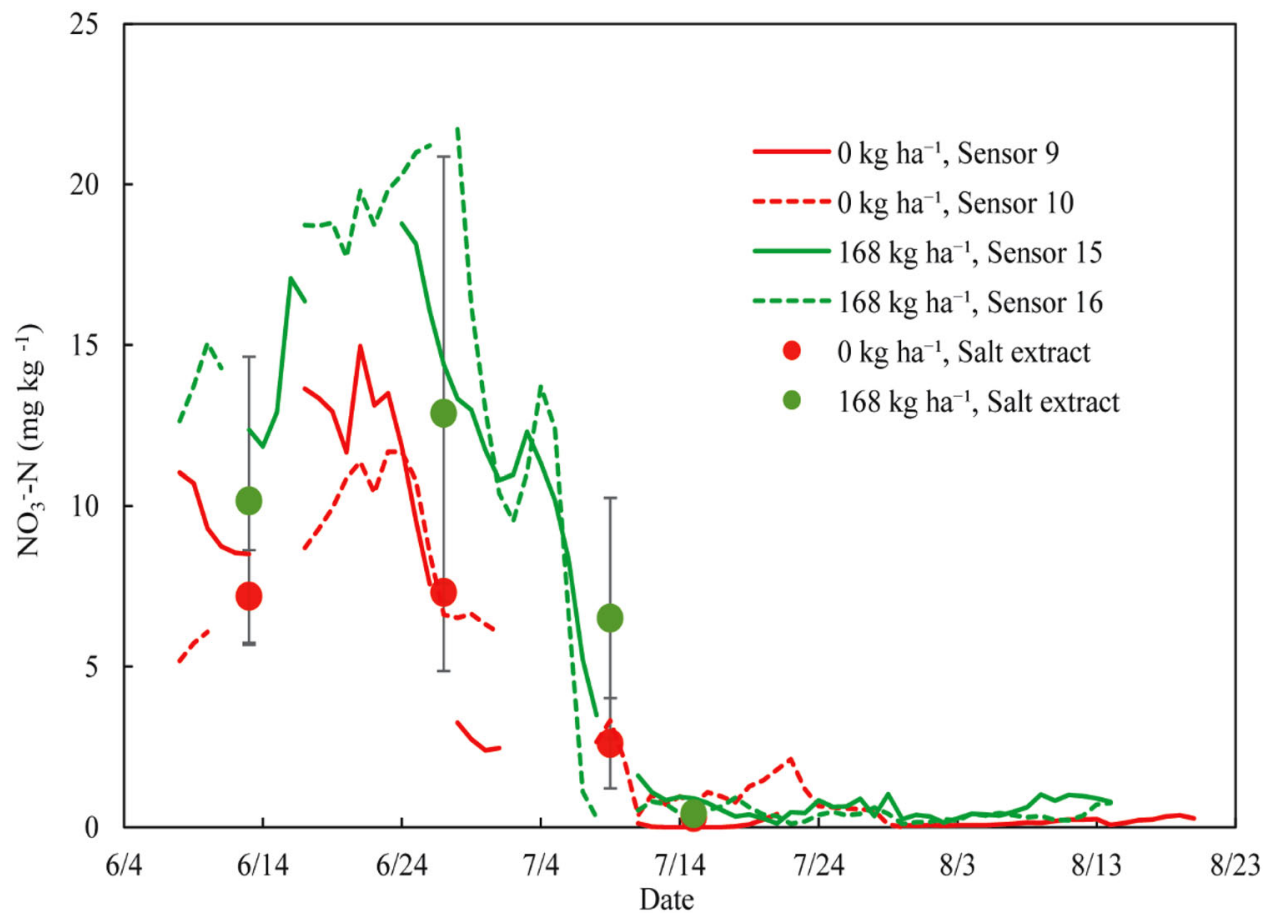

F I G U R E 4 Example comparison between salt extract and sensor measurements of soil $\mathrm{NO}_{3}{ }^{-}$concentration in two field experiment units receiving 0 and $168 \mathrm{~kg} \mathrm{~N} \mathrm{ha}^{-1}$. There were two sensors in each experimental unit (solid and dashed lines). Error bars for the salt extract method indicate standard error of three subreplicate soil samples in each experimental unit sampled within $30 \mathrm{~cm}$ of the sensor 

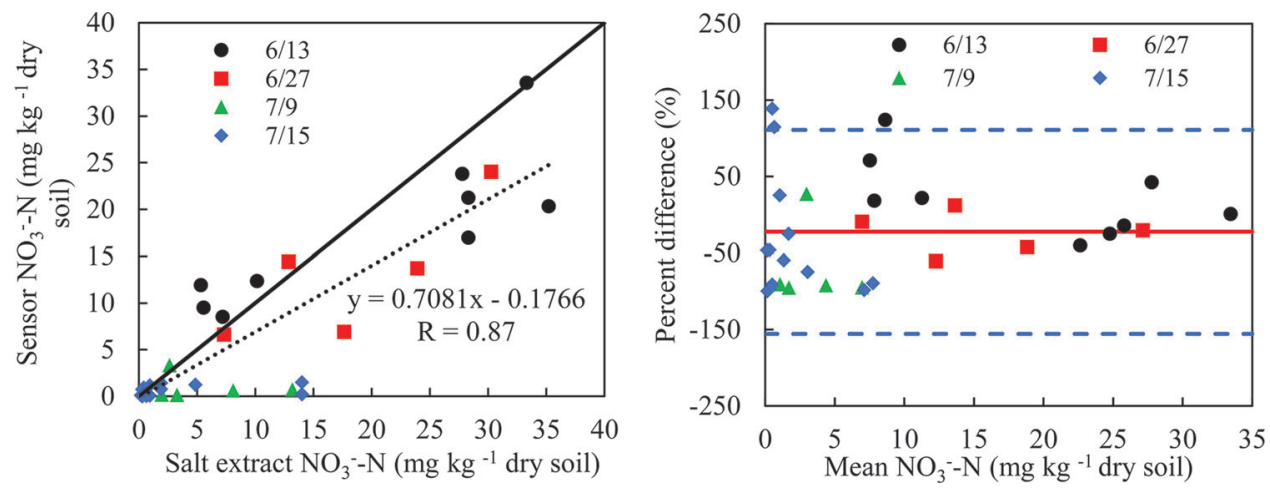

F I G U R E 5 Soil $\mathrm{NO}_{3}{ }^{-}$concentration measured with salt extract and sensor methods in a field experiment. Each point represents one replicate plot in the field experiment on each sampling date. Sensor data represent mean daily soil $\mathrm{NO}_{3}{ }^{-}$concentration on the day of soil sampling and salt extraction. (a) The solid line of equality is shown for reference. The slope of the linear regression model did not significantly differ from 1.0. The equation for the linear equation is $y=0.7081 x-0.1766, r^{2}=.76$. (b) Bland-Altman plot showing percentage differences between salt extract and sensor measurements ( $y$ axis) against the mean of the two measurements ( $x$ axis). The solid red line indicates the mean difference between methods $(-22 \%)$, and the blue dashed lines indicate $95 \%$ confidence intervals (blue dotted line)

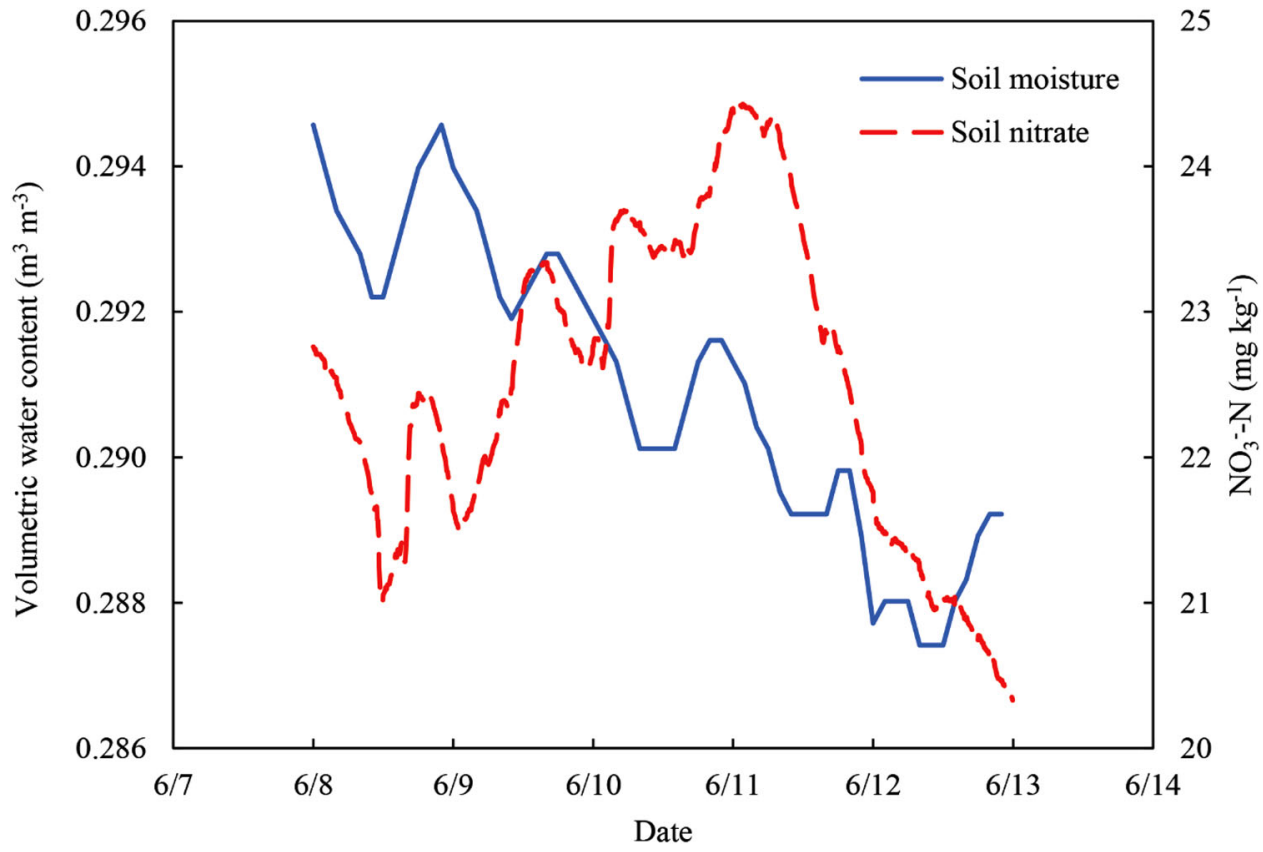

F I G U R E 6 Example comparison of soil volumetric content and soil $\mathrm{NO}_{3}{ }^{-}$concentration in a plot receiving $168 \mathrm{~kg} \mathrm{~N} \mathrm{ha}^{-1}$

differences were large but absolute differences were small (Figure 8).

Across days, as the number of days between measurements increased, the interdaily differences in mean daily $\mathrm{NO}_{3}{ }^{-}-\mathrm{N}$ concentration became increasingly large (Figure 9). However, the effect of sampling interval (i.e., days between measurements) on the estimated mean daily $\mathrm{NO}_{3}{ }^{-}-\mathrm{N}$ concentration differed with the growth stage of maize and seasonal progression from late spring to summer. In the early spring when soil $\mathrm{NO}_{3}{ }^{-}-\mathrm{N}$ concentration was high but stable (8-22 June), sampling interval had a small effect on estimated mean daily $\mathrm{NO}_{3}{ }^{-}-\mathrm{N}$ concentration; linear interpolation of mean daily $\mathrm{NO}_{3}{ }^{-}-\mathrm{N}$ concentration sampled on Days 1 and 8 was within
$5 \%$ of the actual daily mean calculated as the mean of all $8 \mathrm{~d}$. However, when $\mathrm{NO}_{3}{ }^{-}-\mathrm{N}$ concentration was high and dynamic (1-15 July), sampling frequencies with greater than 3-d intervals were $>20 \%$ of the actual daily mean. When $\mathrm{NO}_{3}{ }^{-}-\mathrm{N}$ concentration was low and stable (1-15 August), sampling interval had an intermediate effect on estimation of the daily mean.

\section{4 | DISCUSSION}

The instantaneous, continuous soil $\mathrm{NO}_{3}{ }^{-}$sensors were accurate and measured soil $\mathrm{NO}_{3}{ }^{-}$with accuracy similar to conventional salt-extract methods based on manual sampling 


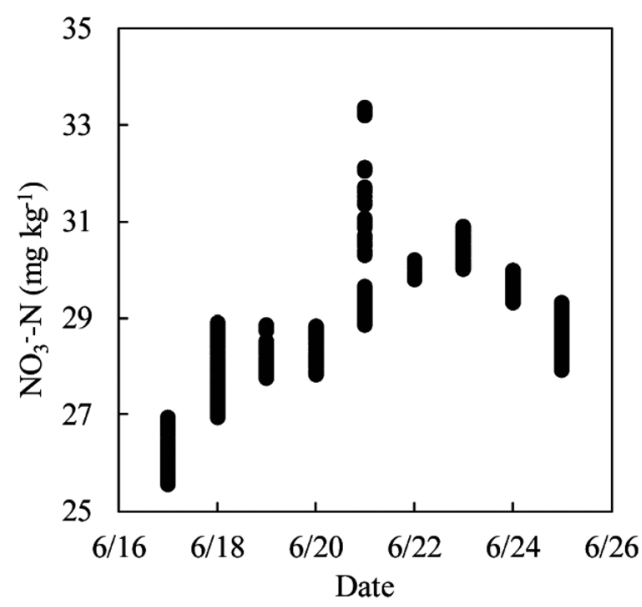

F I G U R E 7 Example daily range of soil $\mathrm{NO}_{3}{ }^{-}$concentration from 10 -s measurements across $9 \mathrm{~d}$ (17-25 June)

(Figures 1-2). The sensors enabled unprecedented temporal resolution of sampling, which demonstrated that diurnal and interdaily variation in soil $\mathrm{NO}_{3}{ }^{-}$pool size are important sometimes, but not others (Figures 6-7). Our results indicate that the sensors can be powerful tools to better understand soil $\mathrm{N}$ cycling processes and better predict ecosystem processes such as crop production, $\mathrm{N}_{2} \mathrm{O}$ emissions, and $\mathrm{NO}_{3}{ }^{-}$leaching.

Due to the difficulty of measuring soil $\mathrm{NO}_{3}{ }^{-}$concentration, current ecosystem models and experiments rely on extremely few empirical data in both time and space. Although subdaily in situ measurements of $\mathrm{N}_{2} \mathrm{O}$ emissions and $\mathrm{NO}_{3}{ }^{-}$leaching are available (Daigh et al., 2015; Jarecki et al., 2008), subdaily measurement of soil $\mathrm{NO}_{3}{ }^{-}$concentration-a critical control on these processes - are unavailable. For example, Jarecki et al. (2008) measured $\mathrm{N}_{2} \mathrm{O}$ emissions every $6 \mathrm{~h}$ for $>200$ consecutive days ( $>800$ times), yet during this time, they measured soil $\mathrm{NO}_{3}{ }^{-}-\mathrm{N}$ concentration only six times. Using these data, the authors demonstrated that the ecosystem process model DAYCENT predicted $\mathrm{N}_{2} \mathrm{O}$ emissions within $25 \%$ of actual emissions. Because $\mathrm{NO}_{3}{ }^{-}$is the substrate for $\mathrm{N}_{2} \mathrm{O}$ production, it is possible that high-resolution $\mathrm{NO}_{3}{ }^{-}$ concentration measurements could have improved the model performance.

Our results point towards significant potential for highresolution $\mathrm{NO}_{3}{ }^{-}$data to advance understanding of soil $\mathrm{N}$ dynamics. During times of the year when soil $\mathrm{NO}_{3}{ }^{-}$concentration was high and dynamic, low sampling frequency both within and across days resulted in substantial errors in linear interpolation-based estimates of mean soil $\mathrm{NO}_{3}{ }^{-}$concentration (Figures 7-9). However, during times of the year when soil $\mathrm{NO}_{3}{ }^{-}$concentration is stable, measurement frequency had relatively little effect on $\mathrm{NO}_{3}{ }^{-}$concentration. These results suggest that sensors may add significant value to improving soil tests and model predictions of environmental $\mathrm{N}$ losses and plant growth.
Although the soil $\mathrm{NO}_{3}{ }^{-}$concentration varied within days (Figure 7), we rejected the hypothesis that this variation is due to the well-known intradaily fluctuation in soil water content (e.g., Figure 6). Volumetric soil water content is well known to follow a cyclical pattern within days due to the daily pattern of plant water uptake. As a result, the intradaily variability in $\mathrm{NO}_{3}{ }^{-}$is likely the result of many factors including differing water potentials and sink strengths (e.g., microbes, crops, and ion exchange sites).

We did not investigate the effect of spatial resolution on measurements of soil $\mathrm{NO}_{3}^{-}$concentration; however, low-N systems (e.g., pastures and forests) may require more sensors in space. The absolute difference between sensors and salt extract measurements was similar at relatively low and high $\mathrm{NO}_{3}{ }^{-}$concentrations (Figure 5a). Hence, the percentage difference was lower at high $\mathrm{NO}_{3}{ }^{-}$concentrations (Figure 5b).

Given the general similarity between sensor and salt extract measurements in laboratory soils (Figures 1-2), it is most likely that methodological and spatial variations rather than sensor accuracy led to the differences in soil $\mathrm{NO}_{3}{ }^{-}$measurements with the sensor and salt extract methods (Figure 4). We compared point-based sensor measurements at $25-\mathrm{cm}$ depth with salt extract measurements based on extraction of several $2.5-\mathrm{cm} \times 30-\mathrm{cm}$ homogenized soil cores. At low $\mathrm{NO}_{3}{ }^{-}$concentrations, the salt-extract method tended to produce higher $\mathrm{NO}_{3}{ }^{-}$concentrations (Figure 4); this difference is consistent with the widespread pattern of a decrease in soil $\mathrm{NO}_{3}{ }^{-}$concentration with depth (Toosi et al., 2014; Wiseler \& Horst, 1993) and the fact that the salt-extract method includes a large fraction surface soils in the sample. As soil $\mathrm{NO}_{3}{ }^{-}$moves downward through the soil profile, the optimum depth comparison between the two methods may change.

In the context of differences between the methods, it is important to note that all soil $\mathrm{NO}_{3}{ }^{-}$measurements are indices - there is no true value of soil $\mathrm{NO}_{3}{ }^{-}$concentration because the soil $\mathrm{NO}_{3}{ }^{-}$pool varies by size in space and with strength of adhesion to soil particles (Darrouzet-Nardi \& Weintraub, 2014). Spatial variation in soil $\mathrm{NO}_{3}{ }^{-}$pool size is enormous; there is often no spatial dependence of soil $\mathrm{NO}_{3}{ }^{-}$ concentration at scales $>2 \mathrm{~m}^{2}$ (Cambardella et al., 1994; Robertson et al., 1988). Moreover, some soil $\mathrm{NO}_{3}{ }^{-}$chemically adheres to anion exchange sites or physically adheres in soil solutions that are bound to soil particles at extremely low pressure potentials. The strength of adhesion varies at a microscale, and these factors differently affect the measured concentration of $\mathrm{NO}_{3}{ }^{-}$in any given sample with any given method (Darrouzet-Nardi \& Weintraub, 2014). Hence, the goal of all soil $\mathrm{NO}_{3}{ }^{-}$measurements is to use the measurements to predict and explain processes of interest such as microbial metabolism, plant productivity, and environmental $\mathrm{N}$ losses. The sensors tested herein show potential to improve prediction and understanding of these processes. 

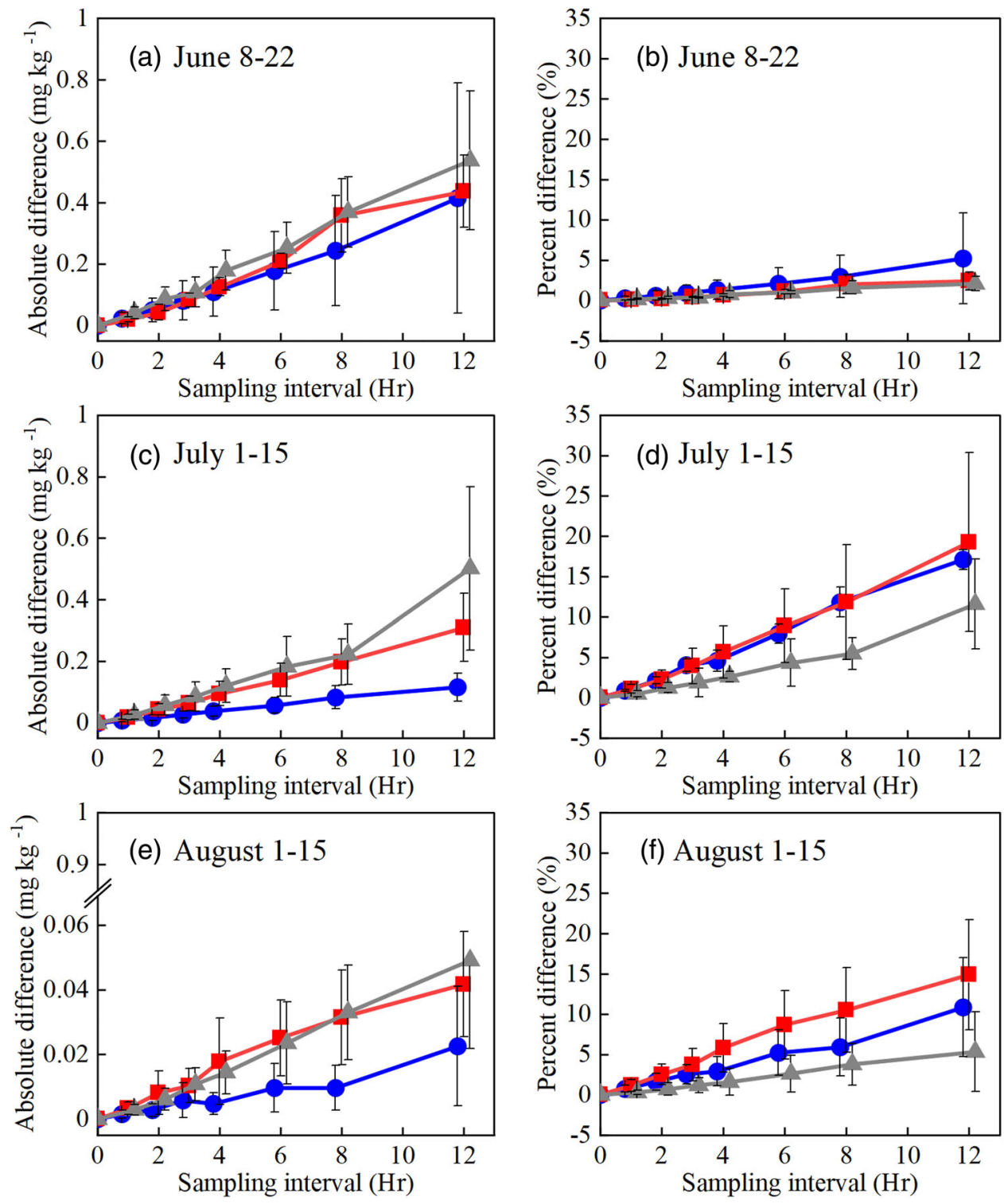

F I G U R E 8 The effect of intradaily sampling resolution on accuracy of estimated mean daily soil $\mathrm{NO}_{3}{ }^{-}$concentrations for a single day in the field experiment. The actual single day mean concentration is calculated as the mean of intradaily field sensor measurements with 10-s sampling resolution. The estimated mean single day concentrations are based on linear interpolation of hourly sampling intervals from 1 to $12 \mathrm{~h}$ (i.e., $24-2$ intradaily samples). Panels represent three time periods that have different $\mathrm{NO}_{3}{ }^{-}$concentrations. Circles represent $0 \mathrm{~kg} \mathrm{~N}$ ha ${ }^{-1}$; squares represent $168 \mathrm{~kg} \mathrm{~N} \mathrm{ha}^{-1}$; triangles represent $336 \mathrm{~kg} \mathrm{~N} \mathrm{ha}^{-1}$. Data are offset from hourly sampling intervals to allow visualization of the error bars

As soil $\mathrm{NO}_{3}^{-}$sensors become low cost and ruggedized for long-term deployment, widespread implementation will advance our capacity to predict, explain, and manage ecosystem $\mathrm{N}$ dynamics. Much more detailed salt-extract, lysimeter, and sensor comparisons will become increasing possible as sensor manufacturing is industrialized. An increase in manufacturing yield will require an industrial setting for manufacturing, quality check, and maintenance.

The recent National Academies of Sciences, Engineering, and Medicine report Science Breakthroughs to Advance Food and Agricultural Research by 2030 (NAS, 2019) highlighted the need for agricultural sensors to deliver research breakthroughs that are required for long-term sustainability of global agriculture. Such sensors have already been realized for soil moisture and temperature. Breakthroughs in soil moisture sensor technology and cost led to improvements in soil evaporation models (Ventura et al., 2006) and distributed sensor networks, which ultimately improved large-scale ecosystem models (Robison et al., 2008). In addition, farmers use the same sensors and similar models to better manage irrigation systems, significantly decreasing water use while improving profitability (Blonquist et al., 2006). Ecosystem and cropping systems can achieve similar improvements from $\mathrm{NO}_{3}{ }^{-}$ sensors. Future work must determine the optimum spatial 

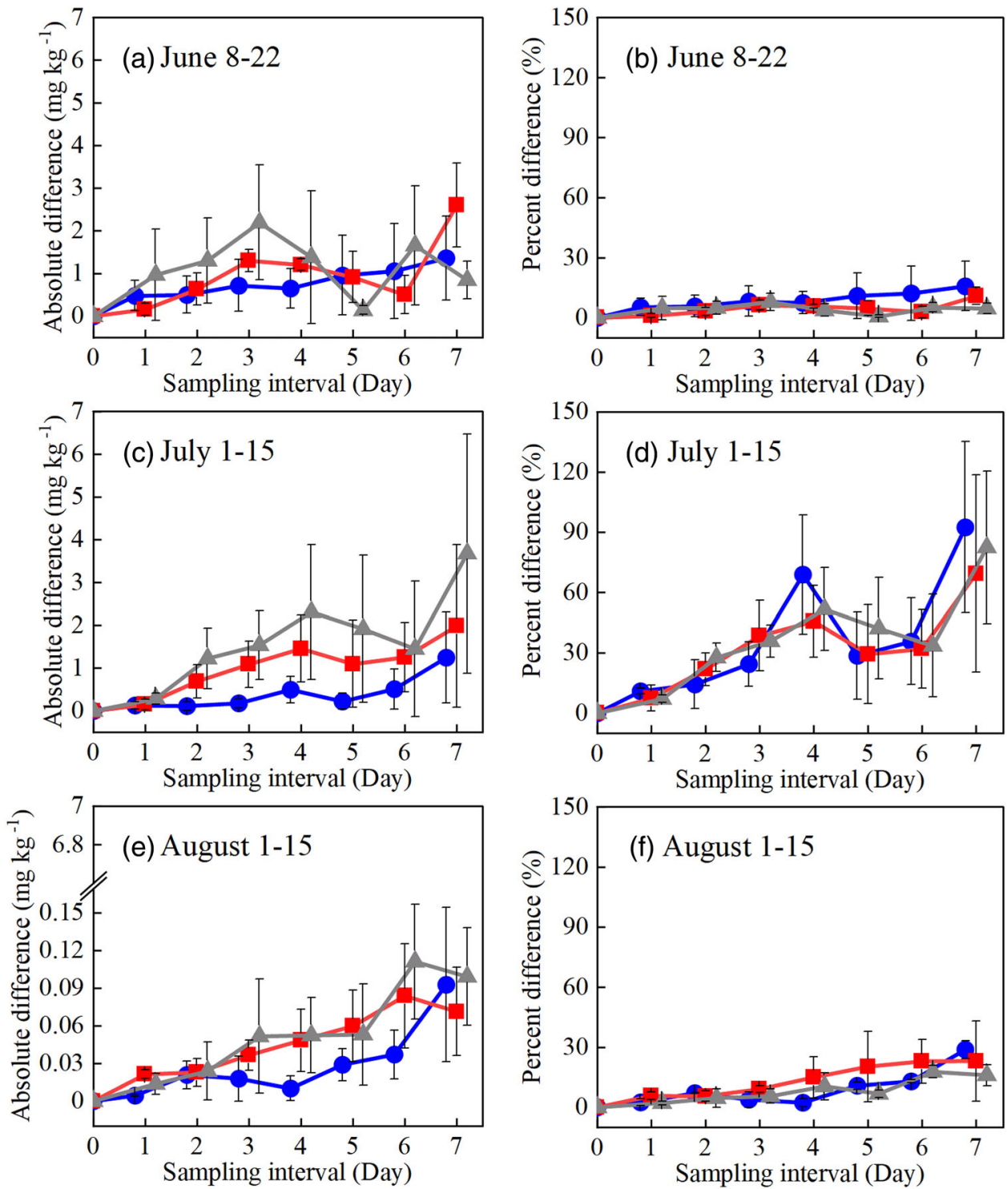

F I G U R E 9 The effect of interdaily sampling resolution on accuracy of mean daily soil $\mathrm{NO}_{3}{ }^{-}$concentration across days in a field experiment. The actual single-day mean concentrations are calculated as the mean of intradaily field sensor measurements with 10-s sampling resolution. The estimated mean daily concentration across days is calculated by linear interpolation of mean daily concentrations with sampling intervals from one to eight days (i.e., 15-2 samples). Panels represent three time periods that have different $\mathrm{NO}_{3}{ }^{-}$concentrations. Symbols represent different $\mathrm{N}$ fertilizer rates. Circles represent $0 \mathrm{~kg} \mathrm{~N} \mathrm{ha}^{-1}$; squares represent $168 \mathrm{~kg} \mathrm{~N}$ ha $^{-1}$; triangles represent $336 \mathrm{~kg} \mathrm{~N}$ ha $^{-1}$. Data are offset from hourly sampling intervals to allow visualization of the error bars

deployment of sensors across depth and area, use sensors to improve model algorithms, and determine how sensor data streams can be coupled with models to enhance predictions.

\section{ACKNOWLEDGMENTS}

We thank Zheyuan Tang and Shengpu Zou for their help with sensor installation and maintenance. This work was performed under the auspices of USDA NIFA Grant 2016-09652 and the USDOE ARPA-E ROOTS program (Award no. DEAR0000824).

\section{CONFLICT OF INTEREST}

The authors declare the following competing financial interest: EnGeniousAg (Ames, IA) has a license from Iowa State University Research Foundation to use the sensor technology tested in this paper and described by Ali et al. (2019). L.D., J.C.S., and M.J.C. have equity interests in EnGeniousAg.

\section{O R C I D}

Yunjiao Zhu (D) https://orcid.org/0000-0001-9966-615X Liang Dong (D) https://orcid.org/0000-0002-0967-4955 Michael J. Castellano D https://orcid.org/0000-0003-14117931 


\section{R E F E R E N C E S}

Ali, M. A., Wang, X., Chen, Y., Jiao, Y., Mahal, N. K., Moru, S., Castellano, M. J., Schnable, J. C., Schnable, P. S., \& Dong, L. (2019). Continuous monitoring of soil nitrate using a miniature sensor with poly(3-octyl-thiophene) and molybdenum disulfide nanocomposite. ACS Applied Materials \& Interfaces, 11, 29195-29206. https://doi. org/10.1021/acsami.9b07120

Archontoulis, S. V., Castellano, M. J., Licht, M. A., Nichols, V., Baum, M., Huber, I., Martinez-Feria, R., Puntel, L., Ordóñez, R. A., Iqbal, J., Wright, E. E., Dietzel, R. N., Helmers, M., Vanloocke, A., Liebman, M., Hatfield, J. L., Herzmann, D., Córdova, S. C., Edmonds, P., ..., Lamkey, K. R. (2020). Predicting crop yields and soil-plant nitrogen dynamics in the US Corn Belt. Crop Science, 60, 721-738. https:// doi.org/10.1002/csc2.20039

Bland, J. M., \& Altman, D. G. (1986). Statistical methods for assessing agreement between two methods of clinical measurement. Lancet, 327, 307-310.

Bland, J. M., \& Altman, D. G. (1999). Measuring agreement in method comparison studies. Statistical Methods in Medical Research, 8, 135160. https://doi.org/10.1002/sim.5955

Blonquist, J. M., Jones, S. B., \& Robinson, D. A. (2006). Precise irrigation scheduling for turfgrass using a subsurface electromagnetic soil moisture sensor. Agriculture Water Management, 84, 153-165. https://doi.org/10.1016/j.agwat.2006.01.014

Cambardella, C. A., Moorman, T. B., Novak, J. M., Parkin, T. B., Karlen, D. L., Turco, R. F., \& Konopka, A. E. (1994). Field-scale variability of soil properties in central Iowa soils. Soil Science Society of America Journal, 58, 1501-1511. https://doi.org/10.2136/sssaj1994. 03615995005800050033x

Daigh, A. L. M., Zhou, X., Helmers, M. J., Pederson, C. H., Horton, R., Jarchow, M., \& Liebman, M. (2015). Subsurface drainage nitrate and total reactive phosphorus losses in bioenergy-based prairies and corn systems. Journal of Environmental Quality, 44, 1638-1646. https:// doi.org/10.2134/jeq2015.02.0080

Darrouzet-Nardi, A., \& Weintraub, M. N. (2014). Evidence for spatially inaccessible labile $\mathrm{N}$ from a comparison of soil core extractions and soil pore water lysimetry. Soil Biology \& Biochemistry, 73, 22-32. https://doi.org/10.1016/j.soilbio.2014.02.010

Del Grosso, S. J., Wirth, T., Ogle, S. M., \& Parton, W. J. (2008). Estimating agricultural nitrous oxide emissions. Eos, Transactions American Geophysical Union, 89, 529. https://doi.org/10.1029/2008EO510001

Efron, B. (1979). Bootstrap methods: Another look at the jackknife. Annals of Statistics, 7. https://doi.org/10.1214/aos/1176344552

Efron, B., \& Gong, G. (1983). A leisurely look at the bootstrap, the jackknife, and cross-validation. The American Statistician, 37, 36-48. https://doi.org/10.1080/00031305.1983.10483087

Fisher, R.A. (1954). Statistical methods for research workers. Oliver and Boyd.

Giavarina, D. (2015). Understanding Bland Altman analysis. Biochemia Medica, 25, 141-151. https://doi.org/10.11613/BM.2015. 015

Hart, S. C., Stark, J. M., Davidson, E. A., \& Firestone, M. K. (1994). Nitrogen mineralization, immobilization, and nitrification. In R.W. Weaver, S. Angle, P. Bottomley, D. Bezdicek, S. Smith, A. Tabatabai, \& A. Wollum (Eds.), Methods of soil analysis: Part 2 Microbiological and biochemical properties (pp. 985-1018). SSSA. https://doi. org/10.2136/sssabookser5.2.c42

Hood-Nowotny, R., Umana, N.H.-N., Inselbacher, E., OswaldLachouani, P., \& Wanek, W. (2010). Alternative methods for measuring inorganic, organic, and total dissolved nitrogen in soil. Soil Science Society of America Journal, 74, 1018-1027. https://doi.org/10.2136/sssaj2009.0389

Iqbal, J., Necpalova, M., Archontoulis, S. V., Anex, R. P., Bourguignon, M., Herzmann, D., Mitchell, D. C., Sawyer, J. E., Zhu, Q., \& Castellano, M. J. (2018). Extreme weather-year sequences have nonadditive effects on environmental nitrogen losses. Global Change Biology, 24, e303-e317. https://doi.org/10.1111/gcb.13866

Jackson, T. J., O’Neill, P. E., \& Swift, C. T. (1997). Passive microwave observation of diurnal surface soil moisture. IEEE Transactions on Geoscience and Remote Sensing, 35, 1210-1222. https://doi.org/10. $1109 / 36.628788$

Jarecki, M. K., Parkin, T. B., Chan, A. S. K., Hatfield, J. L., \& Jones, R. (2008). Comparison of DAYCENT-simulated and measured nitrous oxide emissions from a corn field. Journal of Environmental Quality, 37, 1685-1690. https://doi.org/10.2134/jeq2007.0614

Jaynes, D. B., Dinnes, D. L., Meek, D. W., Karlen, D. L., Cambardella, C. A., \& Colvin, T. S. (2004). Using the late spring nitrate test to reduce nitrate loss within a watershed. Journal of Environmental Quality, 33, 669-677. https://doi.org/10.2134/jeq2004.6690

Koo, T. K., \& Li, M. Y. (2016). A guideline of selecting and reporting intraclass correlation coefficients for reliability research. The Journal of Chiropractic Medicine, 15, 155-163. https://doi.org/10.1016/j.jcm. 2016.02.012

Loecke, T. D., Cambardella, C. A., \& Liebman, M. (2012). Synchrony of net nitrogen mineralization and maize nitrogen uptake following applications of composted and fresh swine manure in the Midwest U.S. Nutrient Cycling in Agroecosystems, 93, 65-74. https://doi.org/ 10.1007/s10705-012-9500-6

Makridakis, S., Wheelwright, S. C., \& Hyndman, R. J. (1998). Forecasting methods and applications. John Wiley \& Sons.

Martinez-Feria, R. A., Castellano, M. J., Dietzel, R. N., Helmers, M. J., Liebman, M., Huber, I., \& Archontoulis, S. V. (2018). Linking cropand soil-based approaches to evaluate system nitrogen-use efficiency and tradeoffs. Agriculture Ecosystems and Environment, 256, 131143. https://doi.org/10.1016/j.agee.2018.01.002

Mueller, K. E., LeCain, D. R., McCormack, M. L., Pendall, E., Carlson, M., \& Blumenthal, D. M. (2018). Root responses to elevated CO2, warming and irrigation in a semi-arid grassland: Integrating biomass, length and life span in a 5-year field experiment. Journal of Ecology, 106, 2176-2189. https://doi.org/10.1111/1365-2745.12993

Müller, R., \& Büttner, P. (1994). A critical discussion of intraclass correlation coefficients. Statistics in Medicine, 13, 2465-2476. https://doi.org/10.1002/sim.4780132310

NAS. (2019). Science breakthroughs to advance food and agricultural research by 2030. National Academies Press.

Parkin, T. B. (2008). Effect of sampling frequency on estimates of cumulative nitrous oxide emissions. Journal of Environmental Quality, 37, 1390-1395. https://doi.org/10.2134/jeq2007.0333

Robertson, G. P., Hutson, M. A., Evans, F. C., \& Tiedje, J. M. (1988). Spatial variability in a successional plant community: Patterns of nitrogen availability. Ecology, 69, 1517-1524. https://doi.org/10. 2307/1941649

Robinson, D. A., Campbell, C. S., Hopmans, J. W., Hornbuckle, B. K., Jones, S. B., Knight, R., Ogden, F., Selker, J., \& Wendroth, O. (2008). Soil moisture measurement for ecological and hydrological watershed-scale observatories: A review. Vadose Zone Journal, 7, 358-389. https://doi.org/10.2136/vzj2007. 0143 
Toosi, E. R., Schmidt, J. P., \& Castellano, M. J. (2014). Soil temperature is an important regulatory control on dissolved organic carbon supply and uptake of soil solution nitrate. European Journal of Soil Biology, 61, 68-71. https://doi.org/10.1016/j.ejsobi.2014.01.003

Ventura, F., Snyder, R. L., \& Bali, K. M. (2006). Estimating evaporation from bare soil using soil moisture data. Journal of Irrigation and Drainage Engineering, 132, 153-158. https://doi.org/10.1061/ (ASCE)0733-9437(2006)132:2(153)

Wang, X., Smith, K., \& Hyndman, R. (2006). Characteristic-based clustering for time series data. Data Mining and Knowledge Discovery, 13, 335-364. https://doi.org/10.1007/s10618-005-0039-x

Wiesler, F., \& Horst, W. J. (1993). Differences among maize cultivars in the utilization of soil nitrate and the related losses of nitrate through leaching. Plant and Soil, 151, 193-203. https://doi.org/10. 1007/BF00016284

\section{SUPPORTING INFORMATION}

Additional supporting information may be found online in the Supporting Information section at the end of the article.

How to cite this article: Zhu Y, Chen Y, Ali A, et al. Continuous in situ soil nitrate sensors: The importance of high-resolution measurements across time and a comparison with salt extraction-based methods. Soil Sci Soc Am J. 2021;1-14. https://doi.org/10.1002/saj2.20226 